\title{
Water Scarcity and Urban Forests: Science and Public Policy Lessons from a Decade of Drought in Adelaide, Australia
}

\author{
Mark Brindal and Randy Stringer
}

\begin{abstract}
Drawing on the experience of greater metropolitan Adelaide, South Australia, Australia, the paper points to the links and gaps between science and public policy. The paper explores urban stormwater management lessons emerging from a ten-year, prolonged dry period that impacted the integrity of urban forests in the City of Adelaide. Among the questions addressed: will stormwater remain, as its historic and institutional settings suggest, a liability or can it become an asset? Who owns stormwater resources and to whom is its management vested? The paper examines these issues with consideration to the dangers of continuing to use urban forestry management practices that are not informed by science. The study concludes that a more integrated approach to urban water management can maintain the integrity of urban forests in ways that potentially enhance social amenities and economic efficiency.

Key Words. Adelaide; Australia; Stormwater; Urban Forest Management; Water Policy.
\end{abstract}

In the urban environment, trees are forced to compete for their water with the conflicting demands of the urban built form: vast areas of impermeable surface and drainage infrastructure designed, traditionally, to ensure that precipitation run-off is expeditiously and efficiently removed. Where they exist, the narrow verges through which street trees are supposed to obtain their water are too often inadequate for that purpose (Connellan 2008; May 2009). A number of studies present valuable evidence as to why this occurs (Whitlow et al. 1992; Wagar and Franklin 1994; Morgenroth and Buchan 2009).

In Adelaide, South Australia, Australia, with an average annual precipitation of less than $600 \mathrm{~mm}$, the urban forest, and in particular street trees, prosper. In recent years, Adelaide's urban forests have faced significant challenges from a ten-year, prolonged dry period (PDP), spanning November 2001 until March 2010. Several key developments during the PDP suggest that the urban forest and street trees are unlikely to maintain their health. First, natural underground water resources provide sustenance for some of the city's street trees, leaky potable water, and sewerage infrastructure for many others. For the most part, it is the proximity to the city's well-watered greenspaces (most of which are privately owned) that contribute to the health of the street tree component of Adelaide's urban forest. However, during the PDP all households were subjected to water restrictions, greatly reducing the amount of water applied to gardens (Government of South Australia 2011).

Second, two recently released government program initiatives require changes to how street trees are managed. The ' 30 Year Plan for Greater Adelaide' (Government of South Australia 2010) and 'Water for Good' (Government of South Australia 2009) programs aim to integrate policy for stormwater and urban forest management. The private and public incentives created by each program impact the viability of urban greenspaces. For example, the 30 Year Plan controls urban sprawl by pursuing urban infill, with potential negative consequences for how impermeable surface areas impact the ability of the urban forest to receive its water requirement through natural absorption.

The Water for Good program enshrines a target for the harvesting of $60 \mathrm{GL}$ of stormwater a year by 2050 to ensure the ongoing viability of the city's potable water supplies. One recent study estimates that urbanized areas in the region produce about 86 GL of stormwater run-off per annum (Government of South Australia 2009). At present, most stormwater flows into the gulf to the west. The volume targeted for collection represents approximately two-thirds of the total estimated urban run-off (Government of South Australia 2004a).

The third development impacting street trees is proposals to reduce leakage in both the potable water and sewerage systems, further depriving the urban forest of water. Because of the water restrictions implemented during the PDP, the suburbs of Adelaide present many examples of abandoned gardens. Some households installed water-wise plants or subsurface irrigation, while others increased areas of impermeable paved surface. Some of these actions may deprive plants of moisture.

Drawing on the experience of greater metropolitan Adelaide during the PDP, this paper aims to highlight the links and gaps between science and public policy that inhibit the capacity to organize more effective institutional structures to manage water for trees. In Adelaide's case, urban stormwater management is the core issue. The paper examines whether the recent experience with stormwater events reveal the city's current institutional arrangements as more of an asset or liability. Why are the tradeoffs of how storm water is managed and used not considered? Who owns storm water, in whom is its management vested and does its management impact the urban forest? This paper seeks to explore these questions, examining the risks for Adelaide's urban forest. It concludes that through a more holis- 
tic approach to urban water management the integrity of urban greenspaces can not only be maintained, but can be enhanced in a manner that improves social amenity and economic efficiency.

\section{OVERVIEW OF ADELAIDE}

Adelaide, the capital city of South Australia, and its metropolitan environs, is the $80 \mathrm{~km}$ long, $30 \mathrm{~km}$ wide urban capital of the driest state on Earth's driest inhabited continent. Despite low rainfall levels and high summer temperatures, Adelaide maintains a higher density of urban trees than many of its Australian capital city counterparts (Kirkpatrick et al. 2011). During most of the last decade, the entire southeastern region of Australia was subjected to a PDP, the result of which included severe water restrictions for Adelaide's private and public gardens. Emerging from this experience are first-hand lessons about the costs associated with stressed landscapes, dead tree removal and the loss of environmental services from the urban forest. The drought also highlights how policy reductionism and cost-center accounting create greater potential for institutional conflicts.

Empirical evidence has long demonstrated that urban forests provide multiple benefits that go far beyond adding aesthetic beauty to neighborhoods. Trees in parks, streets, and yards conserve energy in buildings, improve air quality, reduce storm run-off, and enhance the beauty of communities by adding color, texture, and form to community landscapes (e.g., Dwyer et al. 1992; McPherson et al. 1998; McPherson et al. 1999; Brack 2002; Killicoat et. al. 2002; McPherson and Simpson 2002; Nowak and Dwyer 2007). Additionally, Tarran (2009a) summarizes numerous studies that document the beneficial human health outcomes attributed to urban forests.

Policy failures and the complexities of managing urban forests are also well recognized, if not yet well understood, addressed, and resolved. Developing effective urban forestry strategies and policies involves an array of difficult choices. Some choices result in inefficient resource use because many essential benefits and services of urban trees, such as aesthetic values, watershed protection, and climate regulation, are not priced. These benefits and services are valued differently by different households within the same neighborhoods and across different communities. These values and interests in the urban forest and the resources they provide may differ greatly and have a tendency to shift over time, for example, during a PDP.

As policy interests shift and community expectations conflict, difficult management challenges are created that require innovative, science-informed strategies to better integrate urban trees into community development efforts and balance economic, social, and environmental needs with local interests. The emerging views of what urban trees are and what they contribute requires local governments to search for pragmatic management strategies that deal coherently with the contributions of trees to urban development. Additionally, governments must search for organizational structures that better use of these contributions.

These issues are especially relevant for Adelaide because the city's history and identity are associated with its public space, parks, and gardens. The 'parkland town' is a distinctive feature of the urban scene throughout Australia. Its main elements are a central core of town-lands for business and commerce with a surrounding belt of parklands reserved for public use and a peripheral zone of suburban lands. Williams (1966) described the parkland concept with these three elements, explaining "the whole served by a pattern of roads radiating from the center. This threefold division had its first and greatest expression in Adelaide."

Over time, Adelaide's provision of public open space, streets, and generous-sized housing allotments resulted in household blocks with a mix of fruit trees, native plants, and exotic ornamentals, providing canopies that filled in the linear matrix provided by street trees. Today, viewed from an elevated vantage point, the suburban sprawl is lost beneath a canopy, high-rise buildings appearing to be dotted throughout a forest.

\section{Climate and Trees in Adelaide}

Adelaide is situated on the St. Vincent Gulf in central, southern Australia and has a hot Mediterranean climate (Koppen climate classification Csa; Peel et al. 2007), meaning mild, wet winters and hot, dry summers. Of all the Australian capital cities, Adelaide is the driest. Rainfall is unreliable, light, and infrequent throughout summer. The average monthly rainfall in January and February, according to data collected for more than 150 years, is around $20 \mathrm{~mm}$, but completely rainless months are not uncommon. In contrast, the winter has fairly reliable rainfall with June being the wettest month of the year, averaging around $80 \mathrm{~mm}$. The annual estimated average rainfall for Adelaide is $585 \mathrm{~mm}$. Annual rainfall totals have ranged from a high of $882.4 \mathrm{~mm}$ to $257 \mathrm{~mm}$. In the summer, the average maximum temperature is $29^{\circ} \mathrm{C}$, with around three days a year when the daytime temperature is $40^{\circ} \mathrm{C}$ or warmer (National Climate Centre 2009; Australian Government 2011).

Awareness of the climatological conditions experienced on the Adelaide plains during the PDP is essential to the scientific understanding of the response of the urban forest. The Government declaration that the city was experiencing drought is of interest since evidence suggests it was declared because of a water supply shortfall (Gómez-Muñoz et al. 2010) rather than a lack of precipitation (Australian Government 2011).

While a consistent lack of precipitation throughout the water catchments over the time under discussion led to the drought declaration, precipitation on the city and its metropolitan environs was either average or above average for three of the ten years, and during the summer period (i.e., the time of greatest stress for the urban forest) of two others, there was higher than average summer rainfall. From March 3, 2008, Adelaide recorded 15 consecutive days of temperatures more than $35^{\circ} \mathrm{C}$, again a record for an Australian capital.

In November 2009, another heat wave occurred. Daily maximum temperatures during the heat wave were roughly $10^{\circ} \mathrm{C}$ above average in many locations. From late October until mid-November, the city experienced 10 consecutive days with maximum temperatures greater than $30^{\circ} \mathrm{C}$, six consecutive days over $38^{\circ} \mathrm{C}$, and the highest November temperature ever recorded, $43^{\circ} \mathrm{C}$, on November 19, 2009.

Both heat waves were unusual since the highest temperatures are usually recorded in January and February. Since, locally, these heat waves generally correspond to periods of no precipitation, substantial stress was placed upon the city's urban flora. The combination of high temperatures with the lack of available moisture in the soil profile highlights the stresses to which the urban forest was subjected during prolonged dry periods (Correy 1992; McPherson et. al. 1999; McPherson and Simpson 2003; Gómez-Muñoz et al. 2010). 


\section{INSTITUTIONAL FRAMEWORK FOR TREES AND WATER MANAGEMENT}

The institutional framework within which urban forestry and stormwater are managed in South Australia is complex. The Government is currently working toward integrating all acts related to water into a single piece of legislation. At a legislative level, trees are mentioned in forty different Acts of Parliament or their attendant regulations. These include, but are not limited to:

- $\quad$ The Sewerage Act of 1929

- $\quad$ The Waterworks Act of 1932

- Water Conservation Act of 1936, and various drainage acts

The principal acts governing urban forestry are:

- $\quad$ The Crown Land Management Act of 2009

- $\quad$ The Residential Parks Act of 2007

- The Native Vegetation Act of 1991

- The Environment Protection Act of 1993

- The Natural Resources Management Act of 2004b

- The Development Act of 1993 and the Development Regulations of 2008

Except in the case of designated National Parks (which fall within the jurisdiction of the Department of Environment and Heritage) and on private lands, management and development of the urban forest falls within the jurisdiction of Local Government Authorities, of which nineteen separate authorities constitute the City and its suburban environs. Three other rural councils have jurisdiction over much of the watershed and drainage in the hills to the east.

The institutional settings in respect to water management and ownership are of critical importance since these will have a direct bearing on the future of Adelaide's urban forest. The kernel of the dilemma surrounding the better use and management of South Australia's stormwater for its urban forest is property rights. The Natural Resources Management Act of 2004 vests ownership of the resource in the State Government; each and every right of any individual to take water within the State falls within the jurisdiction of the Government (sec. 124). All rights at common law-that is, those rights that have been previously adopted into the law through usage, custom, and judicial precedent—are abolished (sec. 124.8).

Administrative arrangements are further complicated since they effectively involve three tiers of government. The Water Act of 2007 and the National Water Commission Act of 2004, of the Commonwealth of Australia, confer shared jurisdiction on the Federal Government. The Government only asserts its rights over water or stormwater in stressed areas. At the present time, Adelaide and most of its suburban areas are not 'prescribed.' Prescription is the method by which the government formally asserts its ownership claim, thereby establishing its jurisdiction.

Because government ownership rights can be asserted at any time, local governments seeking to harvest stormwater, or to utilize it in the watering of its urban forest, cannot operate with certainty, since they are utilizing a resource that is not theirs to claim. This ownership uncertainty acts as an impediment to the speedy evolution of the best management practices for the city's urban forest.

The debate about what constitutes 'best practice' in water resource management continues to be hampered by favoring a technical conceptualization of water. In line with this view, water resources management is seen as controlling and governing direct water use and related waste flows, not as managing water's various functions in the landscape (Falkenmark 2003). One key stormwater function is its role in maintaining the health of urban forests.

Evidence suggests stormwater run-off from impervious surfaces can contribute to the collapse of healthy freshwater ecosystems in urban environments (Ladson et al. 2006; Roy et. al. 2008). In the Australian context, research emphasizes an ad hoc approach to stormwater management characterized by partial remedies overly focused on engineering solutions and a lack economic analysis and attempts to integrate policies (Tisdell and Ward 2003; Grafton and Ward 2008; Ward et al. 2008). A recent study focusing specifically on evidence from the United States and Australia identifies seven major impediments to sustainable urban stormwater management (Roy et. al. 2008): 1) uncertainties in performance and cost, 2) insufficient engineering standards and guidelines, 3) fragmented responsibilities, 4) lack of institutional capacity, 5) lack of legislative mandate, 6) lack of funding and effective market incentives, and 7) resistance to change.

In South Australia, the fragmented responsibilities impediment is a significant concern as water is not treated as a single resource with multiple functions, nor are the watersheds considered on a system-wide scale. Water is compartmentalized into three discrete business units: potable water supplies, sewerage water disposal, and stormwater disposal. Unlike many cities where effluent and stormwater disposal are served by common infrastructure, in South Australia, both infrastructures

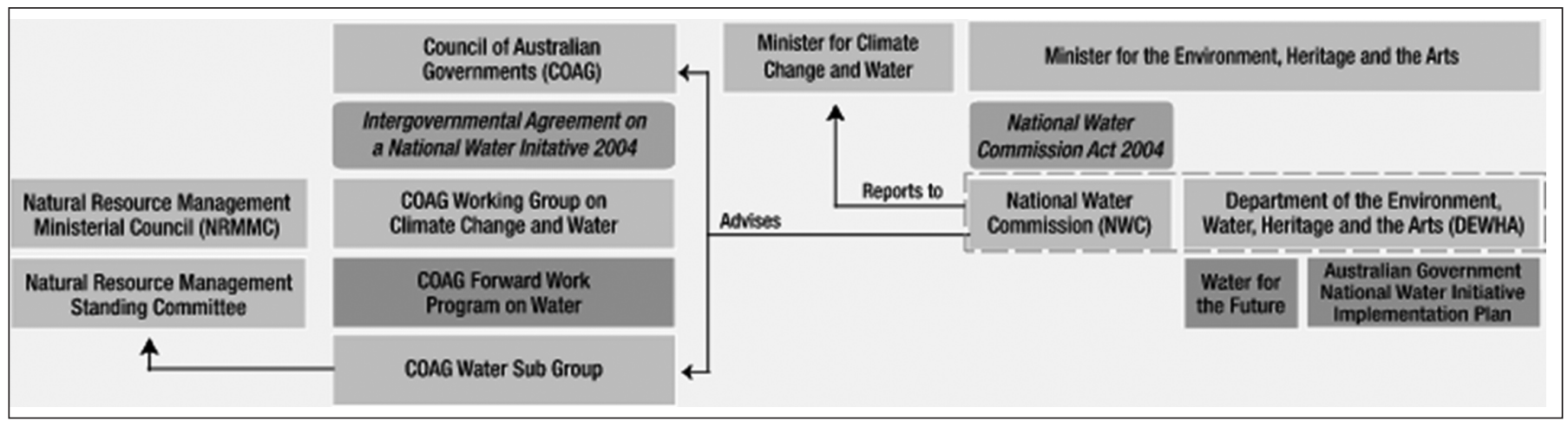

Figure 1. Natural arrangements for water governance (2010). Diagram courtesy of the National Water Commission Archive. 
are discrete: it is unlawful to drain stormwater into the effluent disposal system (Government of South Australia 1929).

While some local council innovations treat the resource in a more holistic manner, urban-wide and watershed-wide integrated management is in its early development stages. Most solutions to date center around demand management through regulation and pricing, the installation of rain water tanks plumbed directly into the household grey-water system, and the watering of parks and gardens using treated effluent rather than potable water (Laurenson et al, 2010).

Figure 1 illustrates national arrangements for water governance. At the state level, three tiers of governance are involved (Figure 2).

The convoluted nature of these interfaces generates haphazard institutional arrangements. Many of the organizational structures result in a silo approach to their perceived areas of responsibility, engendering uncertainty and greatly complicating resource management.

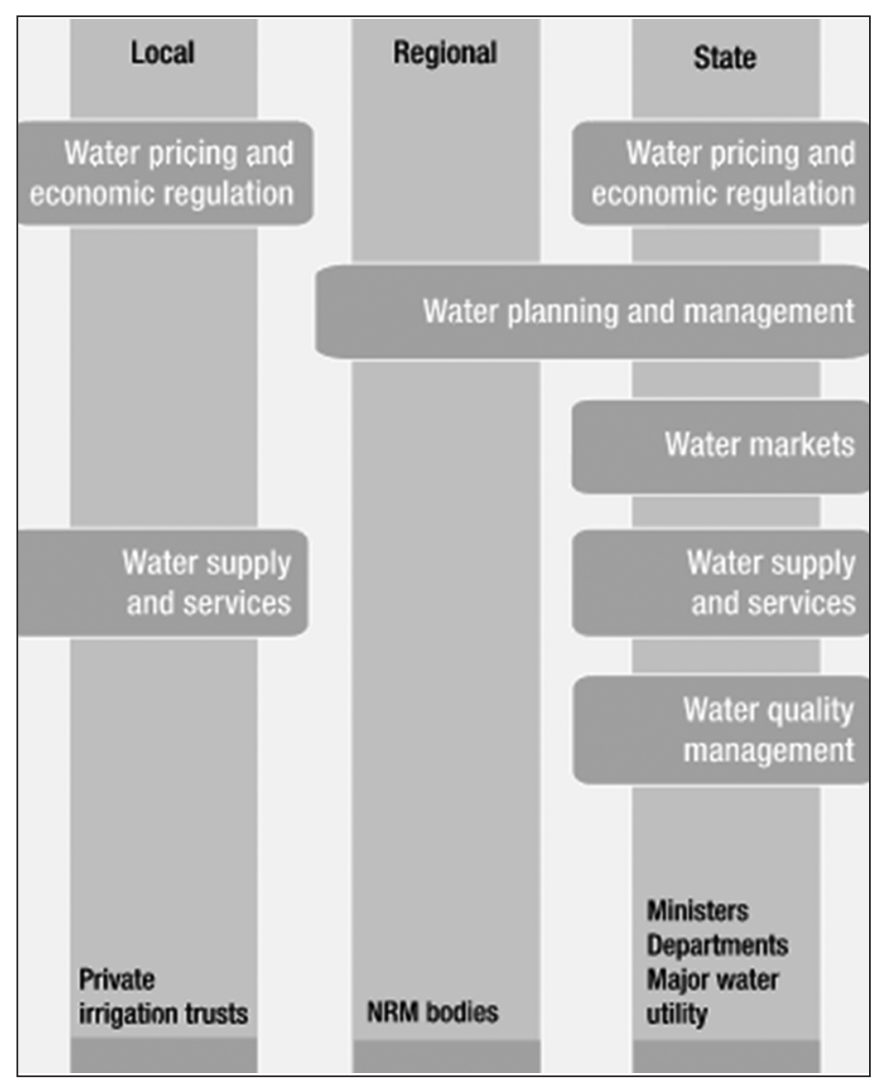

Figure 2. South Australian (state) arrangements for water governance (2010). Diagram courtesy of the National Water Commission Archive.

\section{Seeking and Implementing Science Based Information}

While the relationship between science and public policy is symbiotic, in Adelaide, when necessity dictates, such as with the introduction of policies that which might prove unpopular to constituents (e.g., water restrictions), science is invoked selectively to justify the policy and to seek solutions that lessen negative public reaction. Short-term political expediency too often ignores good science.
For example, substituting treated effluent for the potable water previously used to irrigate the city's parks and gardens, especially within the constraints of what was seen as a drought situation, has public appeal. Adelaide has three main sewerage treatment plants. The northern plant's effluent is used for irrigated agriculture, the southern plant provides grey water for some of the State's premier vineyards, and the central effluent treatment plant discharges the majority of its treated output directly into Gulf St. Vincent. With water restrictions, the Federal and State governments constructed a pipeline to convey treated effluent to the city's parks and gardens. The project proceeded despite warnings by scientists and arborists concerning the long-term viability of the project: the treated effluent has elevated sodium levels and many of the soil profiles to which it will be applied are sodic (Meyer 2008).

To better integrate urban greenspaces with the environment in which the city is situated, some research argues for planting species indigenous to the area (Mibus and Shepherd 2004). In making their arguments, the authors of these studies often ignore the built forms as a major and inescapable factor of the urban environment. Especially in periods such as the recent PDP, calls are made for plantings of water efficient, indigenous, desert region tree species. The aggressive nature of their root systems, with the consequent threat to pavements, road surfaces, and adjacent buildings, is often not considered. Indeed, in some cases, urban environments may be so anthropogenically affected that native plants may be inappropriate as urban habitat.

Most Australian native flora are non-deciduous. Consequently, understory litter problems are continual, and especially where such trees are planted adjacent to roads and walkways, management demands in respect to understory maintenance are higher than for deciduous species. Additionally, many writers suggest that the most beneficial remediation of the urban heat island effect can be most efficiently achieved through the planting of deciduous species, allowing maximum solar warming of buildings in the winter while shielding them from summer radiation (Correy 1992; Brindal and Stringer 2009; Fisher 2009; Gómez-Muñoz et al. 2010).

Lost opportunities notwithstanding, a number of scientific innovations with potential importance to urban foresters have been validated by the climatic conditions of the last decade. An example are projects to collect stormwater runoff directly from buildings or adjacent paved areas, channeling it either into aquifer storage for subsequent irrigation use or dispersing it directly into soil profiles, thus making it available to local trees. The system in one of these projects, Brompton Parfitt Square, is illustrated in Figure 3. Mortality of trees that have access to these projects was, during the decade under examination, zero.

Interestingly, as urban run-off increases, existing infrastructure constraints can provide an unexpected opportunity for innovative urban greenspace design. One residential suburb (Northgate) was recently developed on land that had previously been used for agricultural research purposes. However, because the stormwater infrastructure that carried the water westward to the gulf could not carry the additional capacity, the suburb had to incorporate a series of greenspaces and 
wetlands to retain the stormwater run-off on site, thus making it available to the urban forest in the vicinity.

Other scientific research with empirical evaluation includes a stormwater harvesting trial by a local non-government organization (TREENET). The trial includes the installation, monitoring, and evaluation of stormwater diversion devices (Wark 2003). Each device diverts stormwater from the water table into a soakage trench, then into a soil medium within the verge. The aim is to increase the moisture available to street trees, remove pollutants from stormwater, and reduce the need for tanker watering of street trees.

The proposed TREENET system can be engineered to collect given volumes of water during any rainfall event. It has the advantage of capturing first flush run-off. Importantly, this initial run-off contains all of the environmental 'bads.' Because these pollutants can be captured either by the soakage trench or captured and processed in the root zone of trees, the ecosystem advantages and the smaller amount of remediation required to purify the remaining water in wetlands is axiomatic (Brindal and Stringer 2009). A cost-effective adaptation includes a curbside topographical modification to enable the in situ construction of curbside swales (Kazemi et al. 2011). The emergence of NGOs like TREENET demonstrate how urban forests are gradually becoming topics of discussion among articulate groups of tree specialists, city dwellers, scientists, and educators.

\section{DISCUSSION}

The climatological conditions in southeastern Australia during the last decade have provided unique opportunities for policy makers and scientists alike to better understand the impacts of stormwater on urban forests and opportunities for urban forests to ameliorate drought impacts. The opportunity still exists to improve understanding of these impacts and opportunities both scientifically and in the development of public policy. However, the Australian experience has been characterized more by individuals choosing the science to justify particular policy initiatives than by individuals using the science to uncover optimal solutions.

This paper highlights the issues, links, and gaps between science and public policy that inhibit capacity to organize more effective institutional structures. These gaps are closely aligned with the seven major impediments to sustainable urban stormwater management presented in the findings of Roy et al. (2008). These impediments include:

- inadequate property rights surrounding the ownership and management of stormwater for trees;

- a long tradition of choosing engineering solutions to justify policy decisions;

- no process in place to encourage, seek, or implement science-based information;

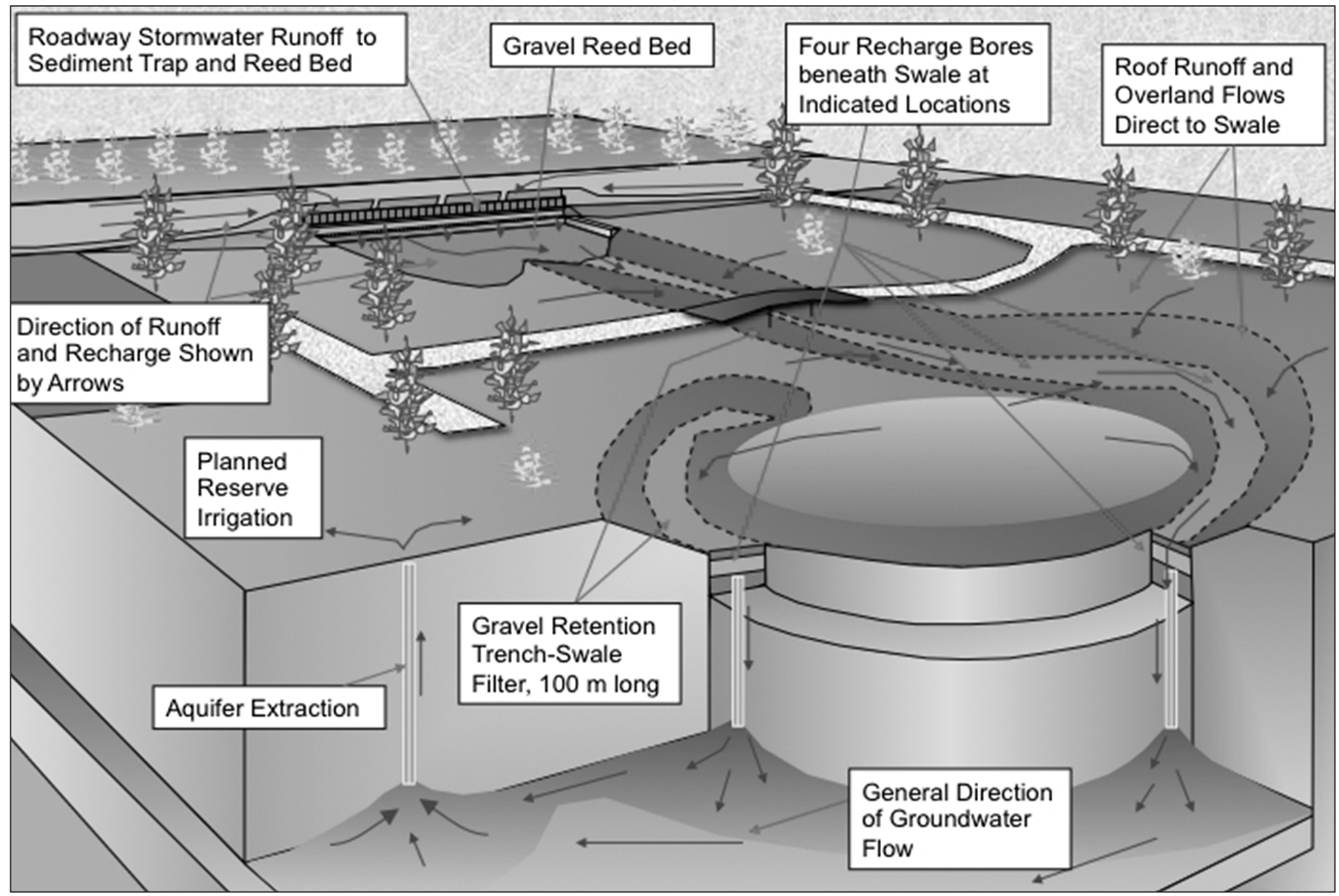

Figure 3. Stormwater Harvesting, Brompton Parfitt Square, South Australia. Diagram courtesy of Brompton Parfitt Square Stormwater Management System, Centre for Water Management and Reuse, University of South Australia. 
- a lack of knowledge and interest in economic incentives and cost-benefit analyses;

- complex administrative arrangements, involving three tiers of government; and

- the city's watersheds and drainages that not considered on a system-wide scale, resulting in fragmented responsibilities.

This paper attempts to demonstrate that these links and gaps impinge negatively on the management of the urban forest. The arguments presented here suggest the need for a much more integrated policy and management approach to address the water needs of Adelaide. Urban foresters are uniquely positioned to lead and to support these initiatives. Developing more effective, integrated urban forestry policies involves an array of difficult choices. Some policy choices result in inefficient resource use because many essential benefits and services of urban trees are not priced. As policy interests shift and community expectations conflict, difficult management challenges are created, requiring innovative, science-informed strategies that better integrate urban trees into community development efforts and balance economic, social, and environmental needs among local interests.

Tarran (2009b) presents a compelling case in that by drawing on theory and methods of natural and social sciences in an integrated manner, the emerging urban ecology discipline will lead to better ways of managing settlements where people live, work, and play. Part of this new management regime includes greater attention to supporting ecosystem functions that influence the quality of life. In Adelaide, the PDP emphasized to public policy managers how and where water flows across the landscape. However, the policy community pays less attention to understanding how capturing and changing stormwater flow impacts the benefits provided by urban forests, or how urban forests could substitute for this infrastructure.

Making use of urban forest benefits requires local governments to search for practical management strategies that deal coherently with the contributions of trees to urban development. In addition, there is a need to search for organizational structures that make better use of these contributions. The science, policy roles, and management of urban forestry (i.e., the knowledge, concepts, institutions, and practices through which multiple and competing demands for trees are managed), is changing as well. The changes are emerging as awareness grows of how local communities control and depend on trees and urban forests, prompting efforts to strengthen local stakes in urban forestry and street tree management, programs, and activities (Killicoat et. al. 2002).

An important message of this paper is that Adelaide's forests need to be better recognized as an integral part of the urban economy. Urban development strategies, from stormwater management to urban infill strategies, need to include the capital values of forests in policy design and program evaluations to understand the consequences of modifying tree stocks, qualities, and distributions. Urban trees need to be more widely acknowledged as both productive capital stocks and as components of public infrastructural systems.

\section{LITERATURE CITED}

Australian Government Bureau of Meteorology. 2011. Climate Data Online. Accessed 09/23/2011. <www.bom.gov.au/climate/data>

Brack, C.L. 2002. Pollution mitigation and carbon sequestration by an urban forest. Environmental Pollution 116:S195-S200.

Brindal, M., and R. Stringer. 2009. The Value of Urban Trees: Environmental Factors and Economic Efficiency. 10th National TREENET Symposium. National Wine Centre, Adelaide, TREENET.

Connellan, G. 2008. Strategies for Urban Trees in an Uncertain Environment. The 9th National TREENET Symposium: 1-9.

Correy, A. 1992. Landscape design dilemma: Australian native trees and solar access conflict. Landscape Australia 2:101-104, 169.

Dwyer, J.F., E.G. McPherson, H.W. Schrodeder, R.A. Rowntree. 1992. Assessing the benefits and costs of the urban forest. Journal of Arboriculture 18:227-234.

Falkenmark, M. 2003. Freshwater as Shared between Society and Ecosystems: From Divided Approaches to Integrated Challenges. Philosophical Transactions: Biological Sciences 3581440:2037-2049.

Fisher, P. 2009. Why we need the Urban Forest Urban Magazine, Urban Development Institute of Australia.

Gómez-Muñoz M., A. Porta-Gándara, and J.L. Fernandez. 2010. Effect of tree shades in urban planning in hot-arid climatic regions. Landscape and Urban Planning 94(3-4):149-157.

Government of South Australia. 1929. Sewerage Act of 1929. South Australia. Version: 4.9.2006.

Government of South Australia. 2004a. Natural Resources Management Act. South Australia.

Government of South Australia. 2004b. Water Proofing Adelaide: Exploring the Issues - a discussion paper. Adelaide, South Australia.

Government of South Australia. 2009. Water for Good. Accessed 05/18/2011. <www.waterforgood.sa.gov.au>

Government of South Australia. 2010. The Thirty Year Plan for Metropolitan Adelaide DPLG. Adelaide: 224.

Government of South Australia. 2011. Waterworks Regulations 2011 under the Waterworks Act 1932

Grafton, R.Q., and M.B. Ward 2008. Prices versus rationing: Marshallian surplus and mandatory water restrictions. Economic Record 84: S57-S65.

Kazemi, F., S. Beecham, and J. Gibbs, J. 2011. Streetscape biodiversity and the role of bioretention swales in an Australian urban environment. Landscape and Urban Planning 101(2):139-148.

Killicoat P., E. Puzio, and R. Stringer. 2002. The Economic Value of Trees in Urban Areas: Estimating the Benefits of Adelaide's Street Trees. Proceedings TREENET Symposium, 94-106, University of Adelaide.

Kirkpatrick, J.B., G.D. Daniels, and A.G. Davison. 2011. Temporal and spatial variation in garden and street trees in six eastern Australian cities. Landscape and Urban Planning 101(3):244-252.

Ladson, A.R., C.J. Walsh., and T.D. Fletcher. 2006. Improving stream health in urban areas by reducing runoff frequency from impervious surfaces. Australian Journal of Water Resources 10(1):23-33.

Laurenson, S., A. Kunhikrishnan, N.S. Bolan, R. Naidu, J. McKay, and G. Keremane. 2010. Management of recycled water for sustainable production and environmental protection: A case study with Northern Adelaide Plains recycling scheme. International Journal of Environmental Science and Development 1(2):177-180.

May, P. 2009. Can Street Trees Survive Drought? The answer lies in the soil! The 10th National Street Tree Symposium 2009:105-108. 
McPherson, E.G., K.I. Scott, and J.R. Simpson. 1998. Estimating cost effectiveness of residential yard trees for improving air quality in Sacramento, California, using existing models. Atmospheric Environment 32(1):75-84.

McPherson, E.G., J.R. Simpson, P.J. Peper, and Q. Xiao. 1999. Benefitcost analysis of Modesto's municipal urban forest. Journal of Arboriculture 25:235-248.

McPherson, E.G., and J.R. Simpson. 2002 A comparison of municipal forest benefits and costs in Modesto and Santa Monica, California, USA. Urban Forestry \& Urban Greening 1:61-74.

McPherson, E.G., and J.R. Simpson. 2003. Potential energy savings in buildings by an urban tree planting programme in California. Urban Forestry \& Urban Greening 2(2):73-86.

Meyer, W. 2008. Glenelg to Adelaide Parklands Recycled Water Project: Monitoring for long term success of irrigating the Parklands. Adelaide, South Australia, University of Adelaide, Earth and Environmental Sciences: 5.

Mibus, R., and I.J. Shepherd. 2004. The development of an Australian style in Australian urban landscaping. Acta Horticulturae (ISHS): $105-112$.

Morgenroth, J., and G.D. Buchan. 2009. Soil Moisture and Aeration Beneath Pervious and Impervious Pavements. Arboriculture \& Urban Forestry 35(3):135-141.

National Climate Centre. 2009. The exceptional January-February 2009 heatwave in south-eastern Australia. Special Climate Statement 17. Melbourne, Australia, Australian Government: Bureau of Meteorology: 11.

Nowak, D.J., and J.F. Dwyer. 2007. Understanding the benefits and costs of urban forest ecosystems, pp. 25-46. In: J. Kuser (Ed.). Urban and Community Forestry in the Northeast, Springer Science and Business Media, New York, New York, U.S.

Peel, M.C., B.L. Finlayson, and T.A. McMahon. 2007. Updated world map of the Koppen-Geiger climate classification. Hydrology and Earth System Sciences Discussions 4:439-473.

Roy, A.H., S.J. Wenger, T.D. Fletcher, C.J. Walsh, A.R. Ladson, W.D. Shuster, H.W. Thurston, and R.R. Brown. 2008. Impediments and solutions to sustainable, watershed-scale urban stormwater management: Lessons from Australia and the United States. Environmental Management 42(2):344-359.

Tarran, J. 2009a. Improving Canberra's sustainability: Why urban tree canopy and other vegetation matters. ACT PLA Bush Capital Workshop

Tarran, J. 2009b. People and Trees: Providing Benefits, Overcoming Impediments, TREENET 2009 Symposium Proceedings.

Tisdell, J.G., and J.R. Ward 2003. Attitudes toward water markets: An Australian case study. Society \& Natural Resources 16(1):61-75.

Wagar, J.A., and A.L. Franklin. 1994. Sidewalk effects on soil moisture and temperature. Journal of Arboriculture 20:237.

Ward, J., P. Dillon, and A. Grandgirard. 2008. Designing tradeable rights to manage aquifer recharge according to robust separation principles. Water Science \& Technology: Water Supply 8(4):427-440.

Wark, A. 2003. Stormwater Harvesting Trial, Claremont Avenue, Netherby, City of Mitcham. Proceedings of the 4th TREENET National Street Tree Symposium: 4 and 5 September 2003.

Whitlow, T.H., N.L. Bassuk, and D.L. Reichert. 1992. A three-year study of water relations of urban street trees. Journal of Applied Ecology 29(2):436-450.

Williams, M. 1966. The Parkland Towns of Australia and New Zealand. Geographical Review 56(1):67-89.
Mark Brindal

University of Adelaide

School of Agriculture, Food, and Wine

Adelaide, South Australia

Australia

Randy Stringer (corresponding author)

University of Adelaide

Global Food Studies

Adelaide, South Australia

Australia

Zusammenfasung. Unter Berücksichtigung der Erfahrungen der größeren Metropole Adelaide, Südaustralien verweist diese Studie auf die Verbindungen und die Lücken zwischen der Wissenschaft und der öffentlichen Politik. Die Studie erforscht die Lektionen aus dem Management des urbanen Sturmwassers aus einer zehnjährigen, verlängerten Trockenperiode, die einen Einfluss auf die Integrität der urbanen Forstflächen in der Stadt Adelaide hatte. Unter der Fragestellung war: wird das Sturmwasser, wie die historischen und institutionellen Begebenheiten suggerieren, eine Belastung bleiben oder könnte es ein Vorzug werden? Wem gehören die Sturmwasserressourcen und an wen ist das Management zu übertragen? Diese Studie untersucht diese Fragen mit der Berücksichtigung der Gefahr des andauernden Gebrauchs urbaner Forstmanagementpraxis, die nicht von der Wissenschaft informiert war. Die Studie ergab, dass ein mehr integraler Ansatz zum urbanen WasserManagement die Integrität urbaner Forste in Bezug darauf erhalten kann, dass soziale Vorteile und ökonomische Effizienz potentiell verbessert werden kann.

Resumen. Basándose en la experiencia metropolitana de Adelaida, South Australia, Australia, el trabajo se refiere a los vínculos y los abismos entre la ciencia y la política pública. El documento explora las lecciones de la gestión de aguas pluviales urbanas resultantes del prolongado período de sequía de diez años que afectó la integridad de los bosques urbanos en la ciudad de Adelaida. Entre las preguntas abordadas: iseguirán las tormentas como lo sugieren las configuraciones históricas e institucionales o se convertirán en una preocupación actual? ¿Quién posee los recursos de aguas pluviales y a quién corresponde su gestión? El documento examina estos temas con consideración a los peligros de continuar con el uso de prácticas de manejo forestal urbano que no han sido informadas por la ciencia. El estudio concluye que un enfoque más integrado de la gestión del agua urbana puede mantener la integridad de los bosques urbanos en formas que potencialmente mejoren los servicios sociales y la eficiencia económica. 